guished, but even the newer terms such as phenetic and patristic were in need of clarification. Dr. Heywood and Dr. G. A. Harrison (Oxford) attempted a clarification of these points. Other contributors to a lively and wideranging discussion were Prof. D. H. Valentine (University of Durham), Prof. D. J. Carr (Queen's University of Belfast) and Dr. G. B. Corbet (British Museum (Natural History)). In conclusion Mr. R. Crawshay-Williams
(Penrhyndeudraeth), the chairman of the session, emphasized the importance of determining the purpose for which a classification was being constructed and of avoiding the fallacy that any one classification was correct in all circumstances.

${ }^{1}$ Gregory, W. G., Trans. Amer. Phil. Soc., Ser. 2, 31, 443 (1941).

${ }^{2}$ Hill, L. R.., Ihm, P., Schnell, P., and Silvestri, L. G. (in the press).

${ }^{3}$ Silvestri, L. G., Hill, L. R., and Möllor, F., Convegno naz. biofis., I (1963),

\title{
OBITUARIES
}

\section{Dr. A. B. Wood, O.B.E.}

Dr. Alexander Beaumont Wood died on July 19. He was born at Uppermill in the West Riding of Yorkshirc on December 21, 1890. Educated at Huddersfield Technical College and the University of Manchester, he graduatod with first-class honours in physics in 1912. He continued in the Department of Physics under Rutherford, gaining his M.Sc. by research in 1913 and seeing much of the pioneering work in atomic physies. In 1914 he was appointed Oliver Lodge Research Fellow in the University of Liverpool, and then lecturer in physics. In July 1915 he became, at Rutherford's suggestion, one of the first two research physicists to work on anti-submarine problems for the Admiralty Board of Invention and Research which was just being formed. The work was started in Rutherford's department and later established in a naval experimental station at Aberdour. There Wood initiated some of the earliest methods of comparing sound intensities and used them to explore sound fields produced by sources in the sea. He was mainly responsible for the design of the first directional hydrophone used extensively in the search for enemy submarines. In 1917 the laboratory was moved to Parkeston Quay. Here Wood used crystal rectifiers as a means of measuring microphonic current and used them to plot the directional properties of hydrophones and sound fields round moving ships. $\mathrm{He}$ also investigated pressure waves from underwater explosions. During this period the group of outstanding physicists working at Parkeston pioneered most of the principles which have since been used for underwater detection, location and destruction.

After the end of the War, Dr. Wood remained in Admiralty service. At a temporary experimental establishment at Shandon, Gareloch, he furthered the investigation of underwater sound-ranging and explosions. He developed the first cathode-ray oscillograph to give a single linear traverse and used it with a tourmaline pressure gauge to record pressure-time variations. He was awarded a D.Sc. degree at Manchester in 1919. When the Shandon Laboratory closed in 1921, Dr. Wood transferred to the new Admiralty Research Laboratory under construction at Teddington, next door to the National Physical Laboratory. While in charge of the Sound Division ho made accurate measurements of the velocity of sound in sea water, developed the use of magnetostriction transducers, and, together with F. D. Smith and J. A. McGeachy, designed the echo depth recorder which is used very widely to-day. In 1936 he was transferred to H.M. Signal School, Portsmouth, where he dealt with radio-location problems. In 1937 he was appointed chicf scientist at H.M. Mining School, where he was in charge of research on mining and countermeasures. He assisted in the first recovery of a German magnetic mine at Shooburyness on November 23, 1939.

In 1943 he rotumed to Teddington as superintendent of the Admiralty Research Laboratory to look after groups dealing with underwater acoustics, infra-red detection, electromagnetics, underwater ballistics, and soon oceanography, in particular the detailed investigation of waves and swell.
In 1946 he became deputy director of research, Admiralty, and was concerned mainly with the administration of science, until he retired in 1950. He immediately returned to Teddington to carry out research, and at the time of his death his scientific interest was still largely in the propagation of sound in the sea, as it was when he started at A.berdour.

Dr. Wood had been a Fellow of the Physical Society since 1920, and a Founder Follow of the Institute of Physics. He was awarded the Duddell Medal of the Physical Society in 1952 for his work on the design of scientific instruments, and the Acoustical Society of America gave him its Pioneers of Underwater Acoustics Award, in 1961. In May this year he returned from a year's work in the United States, where he had many friends. Ho has a long list of scientific publications, and his Text Book of Sound, first published in 1930, was revised threo times. He was made O.B.E. in 1940 for his service to the Navy.

$\mathrm{H}_{\Theta}$ was a welcome visitor in all laboratories, always ready to advise and very ready to help when the work pleased him. From his fifty years' experience in science he could always suggest some way out of a difficulty. $\mathrm{He}$ will always be remembered for his great kindliness.

\section{G. E. R. Deacon}

\section{Mr. William F. Roeser}

Mr. WILliam F. ROeser, physicist at the U.S. National Bureau of Standards, died at his home in Chevy Chase, Maryland, on June 17, at the age of sixty-two.

Mr. Roeser was woll known for his work in the accurate measurement of temperature and heat transfer by thermal radiation. His present position was as a consultant in the Building Research Division. In addition, he had been serving as an expert adviser in planning the forthcoming transfer of the National Bureau of Standards to Gaithersburg, Maryland. Recently he was cited by the Bureau for his exceptionally able contributions in this field, particularly in solving many of the problems of interference at the new site, such as vibration, radiation, and air pollution.

The Meritorious Service Award of Sigma Tau, the national honorary engineering fraternity, was given to Mr. Roeser in 1952 for his achievements in building technology. He also received citations from the Office of the Surgeon General of the U.S. Army, the Manhattan District, the Office of Scientific Research and Development, and the National Advisory Committee for Aero. nautics (Subcommittee on Metals for Aircraft). In 1929 he was awarded the John A. Penton Prize by the American Foundrymen's Association for his paper entitled "Temperature Measurements of Molten Cast Iron".

Mr. Roeser had completed forty-three years of Federal service, all with the National Bureau of Standards. He began as a physicist, carrying out high-temperature research, and progressed to chief of the Mechanical Metallurgy Section and assistant chief of the Metallurgy Division. During the Second World War he contributed to important improvements in prosthetic devices by his research and development work; his investigations of 
solders and soldered joints were especially significant in view of the wartime shortage of tin.

Born in Perry, Oklahoma, in 1901, Mr. Roeser attended Oklahoma A. and M. College, later transferring to George Washington University in Washington, D.C., where he gained a B.S. degree in electrical engineoring in 1925, and an M.S. degree in physics in 1929.

Besides being the author of specialized chapters in such standard reference works as Thermometry and Pyrometry and Standard Handbook for Electrical Engineers, Mr. Roeser wroto numerous articles on pyrometric measurements. He was a special lecturer in electrical engineering at George Washington University from 1925 until 1930. Mr. Roeser was a member of the Washington A.cademy of Sciences, the Washington Philosophical Society, the American Society for Testing and Materials, the American Society for Metals, Sigma Xi, Sigma Tau, the Society of American Military Engineers, and the Building Research Institute.

\section{NEWS and VIEWS}

\section{Anatomy in the University of Aberdeen:}

Prof. R. D. Lockhart

Prof. R. D. LockharT, who has held the Regius chair of anatomy in the University of Aberdeen since January 1939, retires on September 30. He had already served as a surgeon probationer in the Navy during the First World War before graduating in medicine at Aberdeen in 1918. After a year as a temporary surgeon-lieutenant (R.N.), he returned as assistant to Prof. R. W. Reid in the Anatomy Department at his own University, where he remained as lecturer until his appointment to the chair of anatomy in the University of Birmingham in 1931. He was awarded the Ch.M. degree at Aberdeen in 1924 and M.D. at Birmingham in 1932. Throughout his career Prof. Lockhart has been a vigorous exponent of the dynamic aspects of anatomy, emphasizing the value of surface anatomy and the cine film in teaching the action of muscles. Living Anatomy, which he first published in 1948, is now in its sixth edition. Since 1937 he has been responsible for the myology section of Cunningham's Text.Book of Anatomy, and in 1959, with his colleagues G. F. Hamilton and F. W. Fyfe, published Anatomy of the Human Body, a favourite text-book of the medical student in many parts of the world. As honorary curator of the University Anthropological Museum, Prof. Lockhart has cultivated and spread an interest and enthusiasm in physical and cultural anthropology, not the least of his achievements being the acquisition of many valuable items at Sotheby's for exhibition in the Museum. Outside his academic pursuits, Prof. Lockhart has a well-earned reputation as a gardener, and each year, in May and June, his garden is a blaze of colour from the more spectacular of his hundreds of rhododendron bushes. Even in this field of activity he has not been content with the usual or commonplace, for, only a few months ago, his success with this species was crowned with the recognition and commendation of a new plant which he had recognized as a sport several years ago and propagated to produce an unusual specimen of rhododendron.

Prof. D. C. Sinclair

Prof. D. C. Sinclair, who at present occupies the chair of anatomy in the University of Western Australia, has been appointed to succeed Prof. Lockhart to the Regius chair of anatomy in the University of Aberdeen. (The date on which Prof. Sinclair will be able to take up his appointment in Aberdeen is not yet known.) Prof. Sinclair, who is forty-eight, was born in Forfar on August 28,1915 . His father, who was a medical graduate of this University, was medical officer of health for the county of Angus. Prof. Sinclair was educated at Merchiston and at the University of St. Andrews, whero he was first bursar in 1932. He graduated M.B. and Ch.B. with commendation in 1937, and in 1947 was awarded an M.D. degree with honours. After a short period as lecturer in anatomy at St. Andrews from 1939 until 1940 he joined the Royal Army Medical Corps. He was seconded in 1943 to the Australian Ministry of Munitions, and in Australia he became second in command of the Australian Chemical Warfare Research and Experimental
Station in North Queensland. In 1946 he joined the staff of the Department of Human Anatomy at Oxford and in 1950 was appointed lecturer in anatomy in Pembroke College, Oxford. In 1956 he was appointed to his present post in Western Australia.

\section{Applied Mathematics in the University of Durham: Prof. E. J. Squires}

DR. E. J. SqUIRES, recently appointed to the chair of applied mathematies in the University of Durham at the age of thirty-one, went up to the University of Manchester with a State scholarship from Burnage Grammar School, Manchester, graduating B.Sc. in 1953 and Ph.D. in theoretical physics in 1956. He held a junior fellowship in the Theoretical Physics Division at Harwell for three years and an Imperial Chemical Industries fellowship for the same period at Cambridge, where he was attached to Christ's College. His tenure of the latter fellowship was interrupted by a year as Visiting Fellow in the University of California at Berkeley. Since January 1963, he has been a lecturer in mathematical physics at the University of Edinburgh. Dr. Squires's main research interest is in the theory of elementary particles, a field in which he has published numerous papers. He is also the author of a monograph entitled Complex Angular Momentum and Particle Physics (Benjamin, New York, 1963). He succeeds Prof. K. Stewartson, whose appointment to the Goldsmith chair of mathematics in University College, London, was reported earlier (Nature, 201, 1168; 1964).

\section{Botany at Queen Mary College, London:}

Prof. E. A. Bevan

Dr. E. A. Bevan, University lecturer and demonstrator in the University of Oxford, has been appointed to the chair of botany at Queen Mary College (University of London), in succession to Prof. C. P. Whittingham, who moves to Imperial College in October 1964 (Nature, 202,1059 ; 1964). Dr. Bevan graduated from the University College of Wales at Aberystwyth in agricultural botany. He then undertook research work under Prof. G. Pontecorvo while he held the post of assistant lecturer in tha Department of Geneties at the University of Glasgow. He was awarded the Ph.D. degree in 1955. During 1951-54 he was lecturer in genetics and parasitology at Dartmouth College, Hanover, U.S.A., in the Department of $Z$ oology. In 1954 he returned to Britain to the post of lecturer and demonstrator at the Botany School, Oxford. At Oxford he has been mainly concerned in the teaching of genetics and microbiology. His personal research has been on the genetics of yeasts. He was a member of the Committee for the revision of Preliminary and Honours Moderations courses in biology which ultimately led to the establishment of the new course-work.

\section{Botany at Michigan State University : Prof. A. Lang}

Dr. ANTon LANG, director of the Earhart Laboratory and professor of biology at the California Institute of Technology, has been appointed director of the Atomic Energy Commission Plant Research Laboratory, and professor of botany at Michigan State University. He 